\title{
Cante alentejano, um lugar na Ecocrítica
}

https://doi.org/10.21814/anthropocenica.3232

\author{
Teresa Sofia Nobre dos Santos Coelho \\ Centro Interdisciplinar de História, Culturas e Sociedades, Universidade de Évora \\ Portugal \\ t.s.nobre@gmail.com \\ ORCID: B81F-B6AF-8419
}

\section{Resumo}

Este artigo pretende divulgar as conclusões da análise crítica efetuada a um determinado corpus de Cante Alentejano e a relação que este pode estabelecer com o espaço, o lugar-Alentejo. Os usos dessa mesma relação estão enquadrados no âmbito da Ecocrítica, onde são verificadas as cartografias literárias que o enunciador-recetor traça para o mesmo lugar-Alentejo. Neste sentido, corpo/voz, natureza/meio, pensamento metafórico/lugar e literatura oral tradicional/tradicionalista apresentam-se como conceitos que servem de base à análise efetuada.

\section{Palavras-chave}

Cante Alentejano; lugar; Ecocrítica; pensamento metafórico

\section{Abstract}

This article aims to disseminate the conclusions of a critical analysis towards a certain corpus of Cante Alentejano and its relation with the space -the local-Alentejo-. The usage of the relationship still fits in the range of ecocriticism, being possible to assert the literary cartographies that the sender-receptor may draw for the same place-Alentejo. Bearing this in mind, body/voice, nature/environment, metaphorical thought/ place and oral literature traditional and traditionalist present, themselves, as the basis of this analysis.

\section{Keywords}

Cante Alentejano; place; Ecocriticism; metaphorical thought

Num dia de saudosa camaradagem em Coimbra com amigo dilectos, falei-lhes muito do Alentejo. Havia em mim tão comunicativo entusiasmo, que, de súbito, um deles teve esta exclamação muito espontânea "Caramba! Você traz lá dentro o seu Alentejo, como os búzios guardam nas entranhas os ruídos do mar!

(Mário de Castro, 1932)

\section{Introdução}

Ao aceitar-se o desafio proposto pela teoria Ecocrítica $^{1}$, no seio dos estudos literários, pretende-se, com este artigo, dar a conhecer os resultados de

\footnotetext{
1 Para um maior aprofundamento deste conceito, cf. Mendes (2020). Propõe-se, aliás, que estes artigos possam mesmo ser lidos como se estivessem em constante diálogo.
} 
uma análise crítica efetuada num trabalho de investigação ${ }^{2}$, a um corpus $^{3}$ de modas alentejanas, que tornasse evidentes as premissas gerais da Ecocrítica e, em simultâneo, perceber quais os instrumentos formais que o discurso textual usa para tal. Por fim, o desejo da contribuição para um aprofundamento deste género de estudos em Portugal.

Algumas notas prévias.

O lugar-Alentejo, sendo literário, é aqui entendido como um espaço interior, uma paisagem sonora, que habita o imaginário, não só individual, mas sobretudo coletivo, e que também resulta das materialidades do texto, e das perceções, decorrentes dos processos de receção e de identificação. Com efeito, o conceito de lugar aqui aplicado não deve ser procurado nos anais da sociologia ou da antropologia, sob pena de não ser encontrado.

Acresce que esta ideia de lugar é ainda consubstanciada como espaço físico, na medida em que o território Alentejo é detentor de determinadas idiossincrasias. Por exemplo, e sobretudo, se consideradas as teorias de Orlando Ribeiro ${ }^{4}$ que apresentam o homem do Mediterrâneo como elemento concernente à natureza.

\section{Cante alentejano: um corpus de literatura oral e tradicionalista}

Os textos que enformam o(s) Cancioneiro(s) Alentejano(s) - ainda que se possa considerar um, existem vários Cancioneiros regionais - e inscrevem-se no vasto campo da literatura oral, e tradicionalista, sendo objetivo geral deste artigo, compreender como se processa este mesmo registo através da corrente literária da Ecocrítica, cuja génese remonta à segunda metade do século passado.

Na sua componente literária, o Cante Alentejano é constituído por textos designados por modas incluídos nos subdomínios da Literatura Oral Tradicional e da Literatura Tradicionalista, e cuja componente linguístico-discursiva, como corpus específico que é, surge acompanhado de manifestações gestuais e musicais. Consequentemente, a sua substância é complexa e não se manifesta, nem se esgota, numa única dimensão ${ }^{5}$.

Numa análise formal, e apesar de, neste artigo, constarem só alguns excertos exemplificativos, as modas são textos constituídos por estrofes, fundamentalmente quadras e quintilhas, com a primeira a prevalecer. Todavia,

\footnotetext{
2 Este artigo foi redigido a partir da tese de doutoramento Coelho (2019). Tendo em vista a sua publicação, a tese não se encontra ainda disponível para consulta. Saliente-se ainda que, durante este trabalho de investigação foram aplicados, ao objeto de estudo, outros pressupostos teóricos, para além dos da teoria Ecocrítica, contudo, de menor relevância para esta publicação.

${ }^{3}$ Retirado de: https://drive.google.com/drive/folders/18BDZam1tmHAAfvRpwgLTxPNcW93JaeUA. Para este artigo, foram selecionados alguns dos fragmentos textuais, do corpus, que servem o propósito ecocrítico.

${ }^{4}$ Cf. 1986,1989.

${ }^{5}$ Cf. Zumthor (2007).
} 
ressalve-se que a omnipresença da quadra no cancioneiro é verificada em todo o Portugal, no Brasil, em Espanha e nos países hispano-americanos. A estrutura do texto apresenta-se, normalmente, em número de três estrofes, uma para a cantiga (ou letra) e duas para a moda (ou quadra), a maior parte das composições duplica a estrutura apresentando duas cantigas e repetindo a moda. $O$ primeiro verso da segunda estrofe dá o título à composição, por esta razão a moda é considerada a parte mais importante do texto. A uma moda corresponde uma melodia, ou seja, no Cante uma letra específica está sempre associada a uma música específica ${ }^{6}$, e, na generalidade, as cantigas (primeira estrofe) são independentes das modas ao nível do conteúdo. 0 último verso de uma estrofe é também o primeiro da estrofe seguinte (leixa-prem). A rima que regista mais frequência é a cruzada, o verso, o heptassilábico ou redondilha maior, traços comuns ao cancioneiro tradicional português (e não só). A estrutura vocal que executa as modas é formada pelo Ponto que introduz a cantiga preparando a entrada do Alto e, num registo mais agudo, inicia a moda antecipando a entrada dos Baixos, as vozes restantes, maioritariamente masculinas, mas que também podem incluir vozes femininas e infantojuvenis.

As modas alentejanas apresentam uma estrutura musical idêntica desde os primeiros textos recolhidos, finais do século $X I X$, inícios do século $X X$, e publicados na revista $A$ Tradição de Serpa (1982). Contudo, as suas letras sofreram algumas transformações, retratando aspetos sociais numa forma de atualização do modo de pensar do homem alentejano, como é entendido, ou do seu modo de se relacionar com o mundo também em mais rápidas transformações na transição para o século XXI.

Observando o espaço que é tido como o lugar geográfico do Cante Alentejano e, no seio desta delimitação de fronteiras, entre o que é considerado Cante Alentejano pelos seus portadores, distinguindo veementemente o que não é, podem ainda considerar-se as relações de poder que se estabelecem, de forma mais ou menos explícita, entre os agentes que se localizam no perímetro interior da região geográfica, reconhecida para abarcar o núcleo central do Cante, e os agentes que lhe são exteriores.

Note-se que se trata de um contexto de cultura oral e, como tal, a universalidade que lhe é própria, ou não teria sido aliás classificado há poucos anos como Património Cultural da Humanidade, resulta não só da sua variação no tempo, mas também no espaço (detentor também ele de uma temporalidade própria e ritualisticamente condicionante). Ou seja, considera-se frequentemente a coletividade onde a prática existe há mais tempo como a "originária”. Contudo, a deriva no espaço proporciona-lhe estender-se a outros espaços, mais ou menos próximos, por exemplo, ao facto de determinados Povos considerarem

${ }^{6}$ No cancioneiro tradicional português acontece com frequência a mesma letra ser cantada com músicas diferentes cf. Lopes-Graça (1974). 
"únicas" as suas práticas quando os menos desprevenidos constatarão a existência de práticas semelhantes em lugares, por vezes até, bastante afastados.

Deste modo, tecem-se aqui algumas considerações teóricas, em consonância com a análise dos textos, ou fragmentos mais representativos, com a identificação de características formais, e de contextos, que permeabilizem uma maior evidência da teoria Ecocrítica.

Antes de maiores avanços, será o momento para se clarificarem os termos literatura oral ou tradicional e tradicionalista.

Como já referido, os textos que constituem o Cante consideram-se como orais e tradicionalistas, porque são transmitidos oralmente, e apresentam as características linguísticas (nível de língua corrente) e formais, próprias do cancioneiro corrente por todo o país. A expressão literatura oral sublinha o veículo pelo qual essa literatura é transmitida, e a expressão literatura tradicional (do latim traditiōne-, "tradição» +-al ) vinca a ideia que vem de trás, trazer. Consideram-se ainda algumas modas como tradicionalistas, por apresentarem características linguísticas (nível de língua mais cuidado), formais e ideológicas diferentes das do cancioneiro oral. De algumas delas conhece-se o autor, por norma, detentor de baixo nível de escolaridade, e que tende a imitar o que já conhece, ou seja, as quadras de sete sílabas. Como alguns destes textos também entram na corrente da oralidade, por exemplo, algumas quadras de António Aleixo, a fronteira entre o carácter tradicional e tradicionalista pode tornar-se muito ténue, sobretudo porque alguns desses textos tradicionalistas, ao rodarem na oralidade, vão perdendo, por vezes, as suas características de autor e adquirindo traços próprios do cancioneiro tradicional. Esta diferenciação relaciona-se com uma gradação no uso da linguagem, frequentemente, na poesia tradicionalista, todos os versos rimam entre si, o primeiro com o terceiro e o segundo com o quarto, na sua constituição, contrariamente à quadra tradicional onde só rimam o segundo e quarto. No que concerne a abordagem dos temas, na poesia tradicionalista é apresentada uma visão pessoal do mundo, por exemplo, as questões sociais assentam na defesa de um plano ideológico mais vincado que na poesia tradicional. Os autores adotam esta estrutura com o objetivo de se apropriarem daquele texto, criando uma autoria "sua", pretendendo o reconhecimento. Assim, um texto tradicionalista pode-se ir tornando, com o tempo, um texto tradicional, com a perda de características individuais que tinha, entrando no mainstream da literatura oral.

Em suma, as modas alentejanas podem ser consideradas tradicionais, se entraram na tradição, e são transmitidas pela oralidade, ou, tradicionalistas se apresentam autor, conhecidos por poetas populares, ou níveis de linguagem diferentes. Importa, por conseguinte, verificar se alguma destas literaturas- oral ou tradicionalista- pelas suas características, é, mais ou menos, reveladora da presença Ecocrítica nos textos. 


\section{Premissas da Ecocrítica nas modas alentejanas}

De forma complementar, conceitos de outras áreas parecem acrescentar outras interfaces a esta análise. Por exemplo, a noção de nicho ecológico, nos termos de Richard Lewontin (2002, p. 49) por considerar as relações, e interrelações, de uma determinada espécie com o que a envolve, sugere uma aproximação ao conceito de comunidade interpretativa estabelecido por Stanley Fish (1982), no seio da teoria literária, e que se refere a um sistema, ou contexto, de partilha de pressupostos de leitura (em sentido amplo) comuns a um grupo, sobre um enunciado, ou conjunto de enunciados.

Nos seus estudos, Fish apresenta ainda o conceito de leitor cooperante, com o intuito de sublinhar o compromisso que o leitor assume no cumprimento dos critérios de leitura da comunidade interpretativa a que pertence, pondo a tónica na cooperação, não enquanto sinónimo de leitura com qualidade, ou ativa, mas tão-somente de uma aceitação, por parte do leitor, da desconstrução do texto enquanto artefacto que satisfaz as ideias do grupo onde está incluído, numa comunhão de valores, convenções, crenças. Neste sentido, um Grupo Coral Alentejano pode manifestar algumas destas características de nicho, quer pelas relações que o próprio Grupo estabelece entre si, quer pelas que [o Grupo] estabelece com o meio através do discurso textual.

Com foco na observação destes comportamentos, e destas interrelações, pretende-se perceber a visão Ecocrítica desenvolvida por Cheryll Glotfelty ${ }^{7}$ e que a autora apresenta de forma resumida "the study of the relationship between literature and the physical environment" (1996, p. xviii).

Neste seu ponto de partida, a investigadora levanta algumas formulações: "Como é representada a natureza neste texto?"; "Que papel desempenha o cenário físico no assunto do texto?"; “Em que medida as nossas metáforas sobre a terra influenciam a forma como a tratamos?"; "Tendo em consideração a classe social e o género, deverá lugar tornar-se uma nova categoria da crítica?"; "De que formas e com que efeito a crise ambiental se tem infiltrado na literatura contemporânea e cultura popular?", entre outras, às quais pretendemos encontrar alguma aplicabilidade, e em complemento com os estudos de Greg Garrard (2012), uma vez que este teórico se propõe-a repensar e alargar estas, e outras questões, formuladas por Cheryll Glotfelty.

Em articulação, Greg Garrard propõe uma leitura, não exclusivamente enquadrada na Natureza, mas também, numa moldura cultural, assente em figuras da retórica, não num sentido restrito, como o próprio defende, mas sim no sentido da produção, reprodução e transformação do pensamento

\footnotetext{
${ }^{7}$ A partir do ensaio de William Rueckert (1996).
} 
metafórico, o que desperta, de imediato, o interesse. Este autor reflete sobre os usos das alegorias, metáforas, imagens, na relação com o meio, e, nesta interação, são contemplados os contextos físico e social. Greg Garrard amplia assim o olhar ecocrítico de Cheryll Glotfelty, acrescentando ao olhar "verde", o olhar cultural na relação com o mundo; ou, como frequentemente dizem os próprios ecocríticos, "o mapa não é o chão".

Vem à colação, o depoimento de um cantador de Safara (localidade alentejana) no filme de Sérgio Tréfaut $^{8}$ por defender que "foram as cigarras e os pássaros que ensinaram os alentejanos a cantar". Esta declaração encerra, nitidamente, a visão Ecocrítica que se pretende expor, porém, em nada legitima uma génese perfeitamente situada do Cante Alentejano.

Em consonância, é delimitado um corpus que consiga evidenciar as relações existentes entre o humano e o não humano, entre o humano e a comunidade natural (solos, água, plantas e animais), assente na ideia de que vivemos numa comunidade de organismos que interagem.

Nesta ótica, dá-se relevo à cosmovisão do enunciador-recetor ${ }^{9}$ presente na lírica-narrativa ${ }^{10}$ das modas alentejanas, considerando os seus planos ideológicos - momento em que também se reflete sobre as dicotomias literatura oral tradicional e tradicionalista.

As primeiras leituras do corpus indiciam uma notória presença metafórica e para tratamento deste dado, convocam-se duas visões, antagónicas, mas complementares, acerca do conceito de metáfora. Assim, enquanto para o linguista George Lakoff (1987), a metáfora é considerada uma operação cognitiva fundamental, constitutiva da linguagem e do pensamento; o mesmo não se verifica na tese de Donald Davidson (1978), ao defender que a metáfora pertence exclusivamente ao domínio do uso, afastando-lhe outros significados, ou sentidos, para além do literal.

Desta forma, é importante $\overline{\bar{j}}_{\bar{j}}$ perceber se, por exemplo, os textos tradicionais se aproximam mais da construção do lugar-Alentejo, porque se servem de um pensamento metafórico idêntico ao desenhado por Davidson, ou se os textos tradicionalistas, por recorrerem a um maior leque de sentidos metafóricos, a uma maior ornamentação defendida por Lakoff, a afastam.

Como critério adotou-se a classificação temática dos textos sendo opção o tema natureza, por melhor assistir a premissa fundamental da corrente Ecocrítica: a cultura humana está ligada ao mundo natural, influenciando-se mutuamente. Entendem-se o corpo e a voz ainda o corpo e a voz dos actantes,

\footnotetext{
${ }^{8}$ Cf. segmento de Tréfaut (2013) em: https://youtu.be/r8ksK23HbB0.

9 Uma vez que o plano de enquadramento é o das oralidades, adota-se a designação "enunciador-recetor" em detrimento da entidade "sujeito poético", e desta forma, sublinham-se não só as características orais do texto, mas também a sua interatividade, transformando um enunciador (alguém que canta) num recetor (alguém que ouve), em simultâneo.

10 As modas alentejanas, apesar de se incluírem no modo lírico, apresentam elementos próprios da narrativa- tempo, espaço, personagens, ação (rotinas).
} 
ou praticantes, do Cante, como instrumentos na relação que estabelecem durante esta deriva espacial, numa perspetiva Ecocrítica, alargando a noção de mundo, em conformidade com a constatação de Hans U. Gumbrecht (2010) sobre a influência da atualidade no "mundo" dos seres humanos, onde se tornou urgente a procura da razão, do sentido.

O campo de ação da Ecocrítica é muito abrangente, dinâmico e heterogéneo (como o próprio prefixo avança), como tal, nesta análise, é feita uma leitura dos textos provenientes de diferentes lugares. Ou seja, interessa perceber também no seio da urbanidade, os modelos de pensamento e de prática que descrevam a relação e o cuidado com essa mesma relação entre homem alentejano-natureza-cultura. Através desta abordagem, procura-se compreender ainda o modo como é feita a atualização de valores, nomeadamente nas novas gerações, com a recente proliferação de Grupos Corais Juvenis.

Nesta senda, dada a ainda escassa bibliografia sobre a Ecocrítica nos Estudos Literários portugueses, revela-se útil o texto "Gardens in the Dunes: Indigenismo, natureza e poder em perspetiva ecocrítica" (Alves, 2013), em que Isabel Alves faz a leitura do romance de Leslie Marmon Silko, Gardens in the Dunes, sustentada nas referências teóricas de Cheryll Glotfelty e de Greg Garrard, pela sugestão de paralelismos que são possíveis estender ao Cante Alentejano e ao lugar-Alentejo.

Em conformidade, identificou-se, numa leitura holística do corpus, o convencional jardim, como espaço relacional entre o enunciador-recetor e a pessoa amada em

Fui ao jardim passear

Trôxe um ramo d'alecrim,

Para dar ao meu amor

Que não se esqueça de mim

aspeto que também o pode distanciar do espaço físico referencial - o Alentejo - tido como um lugar árido, seco, contrário ao jardim, local verdejante e pleno de vida.

Existe, em acréscimo, mais uma possível interface, mais um pressuposto aferido na análise das modas alentejanas correlacionado com um (sub)movimento ecológico: a permacultura, cujos praticantes descrevem como uma evocação latente do desejo de "voltar para casa". Tenta-se perceber em que medida a discursividade textual se relaciona com a ecologia, bem como a própria relação que estabelece com ela, partindo do pressuposto que este sentimento de "voltar a casa" está presente no Cante Alentejano, mesmo "estando em casa".

Ainda hoje, mesmo mais afastado do campesinato, o homem alentejano é visto como estabelecendo com a terra e o meio uma relação semelhante à dos Povos indígenas (como acontecerá com todos os Povos ligados à terra), quer na 
atribuição de nomes às coisas, quer na execução dos seus comportamentos rotineiros (como, por exemplo, olhar para o céu e prever a meteorologia, fazendo depender a sua vida dessa circunstância). É notória uma dimensão muito forte do oculto na vida alentejana ${ }^{11}$, tal como em outras zonas de Portugal, sobretudo as rurais, ou mesmo pelo mundo. Por exemplo, na revista $A$ Tradição (AA.VV., 1982, p.43), de Serpa, podemos encontrar uma listagem de mezinhas, benzeduras, ditos e crenças populares que ainda hoje regem as vidas dos mais velhos, textos que se incluem na vastidão da literatura oral, e que podem desvelar a oralidade como um espaço cultural afetivo.

A noção de terra e a relação do sujeito com ela (-mãe?) ${ }^{12}$ desempenharam sempre um papel muito importante na história da literatura e, para o homem alentejano, em particular, pela gaveta da História Social, esta significa, sobretudo, poder e alimento. Atualmente, a terra adquiriu outros valores ${ }^{13}$, como verifica João Pedro Reino, num estudo efetuado na Aldeia da Luz, relacionado com o significado da posse da terra, tendo concluído que "(...) a terra funciona como elemento de coesão e de identidade (...) é importante para quase todos os entrevistados, enquanto na agricultura esta concordância já não existe." (2000, p.120).

Não obstante a relevância deste dado, reitera-se que o quadro concetual ecocrítico que se aplica nestes textos não se resume à ideia de terra como sinónimo de chão, mas também num sentido mais abrangente de meio.

$\mathrm{Na}$ ótica da continuidade do desdobramento do conceito de lugar, recupera-se o contributo decisivo do geógrafo Orlando Ribeiro (1986), nomeadamente o seu estudo sobre o homem do mediterrâneo, em particular o homem alentejano, tido como "coisa do mundo" tendo em conta os seus modos de vivência diária, com predominância no exterior. Sublinha-se ainda o valioso

\footnotetext{
11 cf. Delgado (1955).

12 No programa televisivo "5 para a meia-noite", emitido em 27-08-14, na RTP 1, Jorge Cruz, músico e vocalista do grupo "Diabo na Cruz" fala sobre o seu novo trabalho discográfico, onde, segundo o próprio, é feita uma reapropriação da música tradicional. Afirma "É uma tentação renovar a tradição (...) o cheiro a terra é comum a todos, por isso, este tipo de música ecoa em toda a gente, desde os mais novos aos mais eruditos". Sublinha o carácter democrático deste género de música, porque chega a todos. Neste contexto, torna-se curioso o sentido de posse revelado por parte dos agentes do Cante Alentejano, muitas vezes assumindo-se como "únicos" e defendendo que "nem todos o sabem cantar". Por exemplo, em entrevista ao Grupo Coral de Monsaraz, os cantadores confessam "O Orfeão do Porto também canta à alentejana, mas os alentejanos são melhores intérpretes". Ainda um cantador alentejano relata algumas das suas vivências numa taberna local desta forma "Em Santiago de Compostela um grupo de romeiros do Porto dançava e tentava cantar a moda $O$ Passarinho, então a gente aproximou-se e propôs cantá-la como deve ser!". Destaca-se destas peças, transcritas pela autora do artigo, o fator agregador inerente a estes textos e a particularidade do grupo do norte do país dançar a moda, ao contrário dos alentejanos que só a cantam. 13 Uma reportagem da T.S.F. informa que estas alterações continuam a verificar-se. É noticiado "No concelho alentejano de Odemira, o número de imigrantes que trabalha na agricultura está a mudar o rosto das localidades. A geografia social e humana transformou-se e as empresas agrícolas já não vivem sem esta mão de obra. Mas a integração destas pessoas nem sempre é fácil. Entre a população local, há quem não aceite bem esta gente diferente que povoa as ruas.". Retirado de: https://www.tsf.pt/portugal/sociedade/interior/neste-alentejo-ha-caril-e-

turbantes11096331.html?fbclid=IwAR2g6agjMD50AOSVgGYYu6xF8owNGardhapSkcCYNergBtcsE5HimxJ $\underline{\mathrm{Dk}}$
} 
contributo deste autor, no âmbito da geografia, no estudo dos traços específicos da região a sul, sobretudo a transtagana, que permitem melhor compreender o espaço, em especial na averiguação das condições criadas neste lugar para a emergência do Cante ali, e não em qualquer outro lugar.

Considerando um certo pragmatismo inerente à poética alentejana, será através deste que a construção identitária também assentará, e, nessa semântica do dizer que se aproximará do meio e, por conseguinte, permeabilizará a perspetiva Ecocrítica que se deseja observar, colocando o homem alentejano como parte integrante da biosfera.

\section{Alguns exemplos concretos}

Como (a)firmado anteriormente, optou-se por circunscrever a análise crítica mais demorada no tema Natureza. Na verdade, se, no ponto de partida, se considerar a tessitura verbal das modas de parca qualidade literária, talvez, se Ihe for descoberto um valor ecológico, que é o de dar voz à Natureza, faça esquecer o seu relativo valor estético concentrando-nos nos valores éticos, políticos, e até lúdicos, de que um texto literário também se compõe. Note-se que o objeto de estudo é o texto, "pobre" ou "rico" literariamente, mesmo que amputado dos outros textos (musical e cinético - movimento dos grupos - e etnográfico - trajes a rigor e elementos do quotidiano da vida rural, por exemplo).

Com alguns pressupostos da Ecocrítica entre mãos, surge, nesta quadra, a terra como marca do destino que foi fatal ao enunciador-recetor em

Oh Beja, terrível Beja,

Terra da minha desgraça,

Eram três horas da tarde

Quando $\mathrm{m}^{\prime}$ assentaram praça

ou na moda Lírio Roxo

Nestes campos solitários

Onde a desgraça me tem

Brado, ninguém me responde

Olho não vejo ninguém

A destituição do enunciador-recetor funde-se com o meio e torna-se visível também através do recurso à comparação à fauna, e do jogo semântico paronomástico de "penas", como por exemplo, na cantiga de Sou um rapaz pimpão:

Se os passarinhos vendessem

As penas que Deus lhe deu, 
Também eu vendia as minhas

Que ninguém tem mais do que eu

Ou a referência à flora, na moda Montinho, que pode pedir leitura de conotação sexual:

\author{
Fui (a) passear \\ Ao teu montinho, \\ Saiu-me uma rosa \\ Dançando ao caminho
}

Note-se, nestes excertos, como o meio ambiente serve de moldura relacional entre a entidade enunciadora-recetora e chega mesmo a constituir-se como um instrumento na sua intencionalidade comunicacional. Em consonância com a teoria Ecocrítica formulada por Cheryll Glotfelty, Christopher Manes (1996) - capítulo inserido em Glotflety (1996) - afirma que a natureza se apresenta num estado silencioso na nossa cultura, e nas sociedades alfabetizadas em geral, na medida em que o estatuto de locutor é, invariavelmente, desempenhado pelo ser humano, visto como uma prerrogativa exclusivamente sua. Não é que nestes textos também não o seja, uma vez que são expressas emoções, vontades, rotinas, e como se observa nestes versos, de uma forma igualitária, destituindo-se, por vezes, do seu papel de sujeito para se enquadrar na paisagem, ou seja, o eu não se coloca como "origem" do texto, mas é este que parece irromper do silêncio, surgindo do encontro entre o sujeito lírico e a Natureza, designadamente no uso de personificações. ${ }^{14}$

As culturas animistas, aquelas que concebem o mundo natural povoado não só por pessoas, mas também por animais, plantas, e até entidades inertes como as rochas, ou os rios, são entendidos como estando articulados e, por vezes, "sujeitos inteligíveis" capazes de comunicar e interagir com os humanos: pois, para além da linguagem humana, são reconhecidas, segundo Manes (1996, p. 17), as linguagens dos passáros ${ }^{15}$, do vento, das lagartas, dos lobos ou das cascatas- todo um universo de locutores autónomos frequentemente ignorado.

No mesmo texto, Manes refere Foucault a propósito desta hierarquia, por este ter demonstrado como certo tipo de locutores podem ser privilegiados por terem o poder de influenciar a sociedade e a sua maneira de pensar, entre eles reis, padres, autores canónicos e celebridades. Acrescentem-se a esta lista, por exemplo, os Mestres dos Grupos Corais, tal é a relevância social desta figura no Grupo e na população em que se inscreve a sua atividade. Defende Manes que os discursos destes sujeitos são levados a sério por oposição aos "sem sentido"

\footnotetext{
14 Cf. Garramuño (s.d).

15 São estudados os sistemas de comunicação (complexos) dos pássaros, abelhas e símios, não só nas ciências naturais mas também nas linguísticas. Manes reforça no seu trabalho, no âmbito dos estudos do xamanismo «(...) Mircea Eliade writes "All over the world learning the language of animals, especially of birds, is equivalent to knowing the secrets of nature"» $(1996$, p. 17).
} 
e, frequentemente, silenciados os outros locutores como as mulheres, as minorias, as crianças, os prisioneiros e os loucos. O Homem não tira partido do que a natureza lhe diz e, lamentavelmente, a nossa cultura há muito que demonstra que o contrário desta ideia também é verdade.

Para confrontar este silenciar da natureza no pensamento contemporâneo, é reclamada uma ética ambiental viável. Baseada neste reconhecimento, a ecologia tem aproximado o ouvir o mundo não-humano revertendo as práticas modernas de destruição ambiental. Segundo Manes depreende-se facilmente que na linguagem do Humanismo, o discurso do Homo Sapiens é o único assunto que válido, contudo, a ecologia responde, traçando um quadro modesto assente na premissa que se os fungos (uma das mais "baixas" formas numa escala de valores humanos) se extinguissem, os efeitos no resto da biosfera seriam catastróficos. Em contrapartida, se fosse o ser humano a extinguir-se, a maior parte das formas de vida na Terra não o sentiria.

Em afinidade com o exposto até aqui, alguns excertos de Padre António Marvão, erudito local e estudioso do Cante, merecem especial atenção, pela pertinência com que se intersetam, ou relançam, o propósito ecocrítico:

Quando ainda não se falava de radiodifusão já existia a orquestra canora, associada ao ritmo do trabalho do campo. Se o trabalhador rural abria os regos para a sementeira, lá estava a alvéola à cata de vermes que saíam da terra, com os seus trinados de ritmos em "ostinato». Se limpavam as árvores, os pintassilgos e as falochas respondiam ao bater do machado com os seus tímidos e assustadiços gorgeios. Eram os aleluias permanentes em que o campo, o homem e as aves se irmanavam num conjunto admirável, para a renovação da Natureza. (...) o rouxinol associado a Beja, Vidigueira e Barreiro (...) canta-se a pombinha branca associada à namorada(...) o mocho com o coxo e o amor com o cravo roxo (...) o pavão(...) para falar dos olhos da sua amada (...) 0 passarinho aqui serve de mensageiro para transmitir à namorada que também se pode morrer de amor. Estas e outras modas utilizam os pássaros e as aves nos seus poemas, relacionando-os com o amor.(...) Esta riqueza popular revela um povo que canta e dança, num lirismo popular, a sua epopeia de amor e de trabalho, de sacrifício e de alegria. (Marvão, 1997, pp.156-158)

Num registo impreciso, António Marvão sustenta a base da análise Ecocrítica: a Natureza, ou o meio ambiente, como instrumento de comunicação entre as relações interpessoais.

Mais um exemplo:

Diz a laranja ao limão:

"Qual de nós será mais doce?" 
Sou fiel ao meu amor,

Assim ele p'ra mim fosse ${ }^{16}$.

Dos excertos analisados, revelem-se agora alguns que apresentam características de linguagem que os aproximam mais da literatura tradicionalista, como o uso de termos mais eruditos, ou visões mais "cultas". Tomem-se como exemplo os versos, na terceira pessoa, da moda Ao romper da bela aurora:

Ao romper da bela aurora

Sai o pastor da cabana

Vai gritando em altas vozes

Muito padece quem ama

Os versos da moda Alecrim, gravada na Vidigueira

Vai-se o dia, vem a noite,

Atraz [sic]do inverno, o verão

Tudo no mundo (se) renova

Só a mocidade não

cujo carácter tradicionalista é visível no tema: a passagem de tudo e da ciclicidade na natureza - exceto a da vida humana, linear e irrepetível. Porém, nenhum destes textos exibe assinatura de autor.

Outros fragmentos dialogam de forma mais próxima com os contextos tradicionais, quer pelo uso de léxico mais corrente, e fonemas regionais, quer pelas alusões às rotinas. Neles, o enunciador-recetor estabelece uma relação mais íntima com a natureza, como sendo dela parte integrante, nomeadamente no início da moda, pois em alguns casos verificamos a cantiga (solta) reveladora de traços tradicionalistas:

Ao passar a ribeirinha

Pús um pé e molhei a meia,

Não casei na minha terra

Fui casar a terra alheia

Mostra-se aqui, simbolicamente, o espaço "ribeira" como uma marca de separação entre a vida de solteiro e a vida de casado. Ou o prenúncio de um encontro amoroso(?) no caminho traçado entre

o monte da Légua às Pias

Já não se pode ir à missa

Que se encontra no caminho

16 Letra e música: Popular (Alentejo)Arranjo: Monda e Ruben AlvesIntérprete: Monda (in CD "Monda", Monda/Tánaforja, 2016) 

A Maria Campaniça/
A Maria Campaniça
Que lindos olhos que tem

a projeção de um lugar (conotativo?) em

Todas as bem casadinhas

Vão para o cerro da neve

Eu também p'ra lá hei-d'ir

Antes que a morte me leve

O uso da personificação em

Ó cana rial (sic) das canas

Quem te mandou aqui vir,

S'eu te quizesse (sic) matar

Quem te havia de acudir

O jogo semântico do nome próprio Margarida (peixe e pessoa) e o uso da metáfora para o amor em

Se fôres ó mar, pescar

Pesca-me uma Margarida,

Margarida da minh'alma

Qu'andavas no mar perdida

As imagens metafóricas, ou mesmo composições alegóricas, em Tenho barcos, tenho redes:

Ó meu amor não embarques

Olha que o mar tem travessas

Eu ía p'ra embarcar

-Olá menina olé-

Achei o mar ás avessas

Tenho barcos, tenho redes

Tenho navios no mar

Tenho um amor tão catita

Não m’o deixam namorar

Vejam-se, ainda, a personificação presente no verso Um canivete a bailar ou o jogo semântico da catacrese subentendida (pé de salsa/ pés da cama): "Um raminho de salsa crua,/ Aos pés da sua cama" na moda de peditório Chacotas.

Novamente o uso da personificação e da paronomásia em

Despediu-se o sol de Aurora

E Aurora ficou chorando,

Cala-te Aurora não chores, 
Que eu virei de quando em quando

Note-se também a imagem no texto

Oh coração, praia

Das embarcações

Onde desembarcam

As minhas paixões.

ou, na Moda de Mértola, a cantiga a ilustrar o sentimento (universal) da afeição pelo "seu" lugar:

Mertola, querida Mertola

És minha terra natal,

És bonita como todas,

As terras de Portugal

0 recurso metafórico impõe-se verdadeiramente na estrutura formal destes textos. Veja-se, por exemplo, em 0 Andorinha a voar:

Há ondas meu bem há ondas

Há ondas sem ser no mar

Há ondas no teu cabelo

Há ondas no teu olhar

O Andorinha a voar

E no bico leva a Flor

Passeava a noite inteira

sem falar ao meu amor.

Pelo nível de linguagem, menos corrente, sugere-se uma classificação próxima de um texto tradicionalista, pondo em prática uma certa sofisticação metafórica: a plurissignificação do vocábulo ondas, a figura do marialva no Andorinha e a Flor como uma das raparigas.

Atente-se ainda na moda Ó águia que vais tão alta, na polissemia paronomástica do termo penas na metáfora da cantiga e no uso de linguagem que denotam a proximidade ao carácter tradicionalista:

As penas que andam voando

Espalham o vento norte

Estas que eu tenho em meu peito

Que as espalhem a morte.

Estes exemplos reforçam a funcionalidade destes textos, as relações interpessoais, modos de pensar e de sentir, expostos através do pensamento metafórico, assente na paisagem envolvente, a partir de elementos da natureza. 
Na verdade, integrando a ambiência destes textos ao nível da Ecocrítica, nomeadamente quando o enunciador-recetor se dirige à figura desejada, tratando-a por "rosa" ou "pomba", sendo ele próprio um elemento afeto à natureza, é possível aceitar que será mesmo este o significado que se pretende transmitir.

A demonstrar esta ligação próxima que se pode estabelecer entre as ciências exatas (geografia, ecologia) e as humanas (literatura, linguística, semântica), surgem ainda, por exemplo, os topónimos-- muito presentes nas modas- que contam histórias, traduzindo relações que existiam entre os locais e quem Ihes atribuiu o nome. Nesta esteira, Hermann Lautensach (1989, p.848) descreve a região do Alentejo meridional com as características de um país colonial: grande propriedade, fraca densidade populacional e enorme extensão de incultos. As marcas toponímicas são deixadas pela Reconquista: referências ao culto cristão ou nomes de santos, a maioria importada de outros países cristãos ou do norte de Portugal. Por exemplo, nomes como Pavia, Sabóia, Grândola, Oriola (Orihuela) indicam a fixação de estrangeiros, e, nesta medida, fixaram no "novo" espaço físico, o espaço que transportavam emocionalmente. Os nomes de villa quase só aparecem numa forma modificada pelos árabes, exemplo, Ourique (-ique). No mesmo capítulo, o autor explica a funcionalidade dos caminhos a pé, lugar recorrente nas letras das modas alentejanas (o caminho para o trabalho, o caminho para o monte...)

Os caminhos a pé têm dupla finalidade. Por um lado ligam a aldeia ou o casal aos campos mais próximos, de tal maneira que, nas regiões mais povoadas de Portugal, cada aldeia é o centro de uma verdadeira rede de veredas, que têm raras ligações com as vizinhas. Mas, nas regiões montanhosas, os caminhos a pé servem também para as comunicações à distância(...). (Ribeiro, Lautensach \& Daveau, 1989, p.851)

Os autores exemplificam com uma quadra "popular", cantada pelos autóctones, para legendar estes caminhos, provando o que se defende:

Quem subir à Serra de Ossa

Tem de ir bem devagarinho

Tem de apartar as estevas

Que lá há pelo caminho. (Ribeiro, Lautensach \& Daveau, 1989, p.851)

As restantes modas toponímicas de autor desvelam, na sua estrutura formal, traços notórios de textos tradicionalistas, onde são veiculados quadros ideológicos acerca da ação do Homem e do seu contributo para um "mundo melhor". Nesta ótica Ecocrítica, algumas letras tendem a promover práticas neste sentido, visando a alteração do comportamento humano, à semelhança do que acontece no supra-referido Gardens in the Dunes: 
Terra onde cresce a semente

Que vamos levar ao silo

Ai quando é que toda a gente

(Ai quando é que toda a gente)

Aprende a reparti-lo

Num paralelismo com um dos aspetos da leitura que Isabel Alves (2013) faz do romance de Leslie Silko, igualmente já referido, uma das personagens desta narrativa tem como meta colecionar plantas e desenvolver os seus conhecimentos de botânica para, mais tarde, quando regressar das viagens que efetua, à sua terra- old gardens - poder aplicá-los encetando, assim, uma forma de regeneração do lugar. De igual modo, o Povo Alentejano, designadamente o que (e)migrou, parece desejar o mesmo que aquela personagem: regressar ao seu lugar Alentejo, numa lógica de regeneração e de reanimação de certas práticas.

Nesta esteira, os jardins podem assumir-se como espaços de encontro, de confluência de civilizações e, em simultâneo, como símbolos de resistência política, leitura que também é permitida aplicar ao Povo Alentejano, na medida em que subjaz na sua poética uma forte ideologia política de base. Como propõe ainda a mesma autora, estes "jardins" representam a possibilidade de coabitação e a necessidade de adaptação, soluções que, eventualmente, poderiam ser extensíveis como respostas, às anunciadas alterações que a sociedade atual exige ao Cante Alentejano.

À semelhança do comportamento das personagens de Silko, o sujeito Alentejano presente na cartografia literária do Cante, manifesta uma forte dependência da sua relação com o meio, uma vez que dele é parte integrante, reclamando como "sua" a geografia transtagana. Nesta perspetiva, estes textos podem ser recebidos como exemplos de "ecologia etnopoética", nos termos de Buell (1996) (citado em Alves, 2013, p. 217) uma vez que, e através do exercício metafórico, são criadas inter-relações envolvendo cada elemento do meio circundante (a pedra, a silva, a rosa, mesmo as próprias localidades pelo uso dos topónimos) na experiência vivida; ou emocional, do enunciador-recetor.

Um dos elementos incluídos, na área vocabular de Alentejo, é o lugar monte, termo também frequente no léxico das modas. A este propósito, Orlando Ribeiro afirma que:

0 monte alentejano pode considerar-se uma forma de aglomeração(...). O monte é um todo, uma unidade, voltando para o campo paredes de poucas aberturas; pelas acomodações de gados, alfaias campestres, palhas e grãos; pelos animais de criação e de trabalho que asseguram a lavoura e dão o estrume; pelo pessoal permanente que exerce os mais variados mesteres- guardas de herdade, carpinteiro, abegão, sota, boieiros, cozinheiro, amassador, 
carreiros e ganhões, hortelão, tratador de cavalos, paquete, maioral de ovelhas com seus entregues e ajudas, porqueiros, vaqueiros, eguariço e cabreiro; pessoal reforçado na época das principais fainas agrícolas com as camaradas de ceifeiros-ratinhos [vindos sobretudo das Beiras], tosquiadores, mulheres para a monda, a apanha da azeitona e da bolota e ainda outros assalariados. Nalguns montes há capela particular, expressão de independência, no campo espiritual como no material, destes agrupamentos humanos. (Ribeiro, Lautensach \& Daveau, 1989, pp.862-864)

O monte pode assim ser comparado a um organismo vivo, recuperarando um conceito já usado, um nicho ecológico. Expõe-se, e justifica-se assim, a maioria das práticas que figura-nas modas, e que traduz a ligação do sujeito enunciador-recetor à terra. Como tal, alguns Grupos Corais adotam nomes relacionados com estas atividades: Os Ganhões, Os Ceifeiros, Os Vindimadores, entre outros.

A sublinhar a tendência tradicionalista da maior parte das cantigas, através da presença das aspirações pessoais do sujeito enunciador-recetor, note-se ainda, nesta quadra, a evidente crítica sociopolítica:

Se entrares no cemitério

Tira o chapéu que é devido

Virás (oralidade) o pobre na terra

E o rico no jazido [sic]

Sob um prisma ecocrítico, também geopoético, e mesmo se se convocarem alguns dos princípios subjacentes à teoria da proxémia, neste microespaço - cemitério - parece estabelecer-se um paralelismo entre os dois mundos - o terreno e o inteligível - que se assemelham, por exemplo, na distinção entre as classes sociais, como se um fosse o prolongamento do outro, na relação construída com este lugar.

Noutra moda, sobressai ainda o pragmatismo no uso da personificação nos versos
Abre-te campa sagrada
Que a minha mãe quero ver
Quero-lhe beijar o rosto
Antes da terra o comer
Antes da terra o gastar

Para além do imperativo dirigido a um objeto, sobressai a relação cíclica criada entre o sujeito enunciador- recetor e a terra: "dela vieste a ela regressarás", minimiza, de alguma forma, a primazia do indivíduo, sobre a natureza, nivelandoos. 
Em trabalho de campo e entre os Grupos Corais, é recorrente ouvir-se que existem diferenças no Cante entre a margem direita e a esquerda do rio Guadiana. Perante estes testemunhos, tendo em mente o exposto por Isabel Alves, tome-se o elemento rio como uma marca distintiva entre os diferentes ritmos de cantar das populações, que traduzem "a sua maneira de falar" e, por sua vez, formas de estar, de viver. As da margem direita, tidas como mais melismáticas, mais lentas, mais dolentes, mais solenes, menos "folclóricas", citando os autóctones. A localidade que "lidera" a margem esquerda é reconhecida, e socialmente aceite, atribuída a Serpa e a da margem direita, a Cuba. Nasce aqui, a competitividade, ao nível da performance entre as duas, por questões históricas e de liderança. Sublinhe-se que estas afirmações não têm mais que uma base empírica, não obstante, e como se afirmou, à luz das premissas da Ecocrítica adquirem alguma consistência literária: o rio Guadiana pode ser visto como uma metáfora do próprio Cante, elemento dinâmico, que se mantém vivo, em movimento, separado pelas margens, mas propriedade de ambas.

Dadas as características já reconhecidas nesta forma cultural assente na literatura oral, não faz sentido defender uma posição monolítica do Cante Alentejano, mas antes promover uma recetividade à sua versatilidade, sublinhando a existência fugaz de um texto oral, que só permanecerá naquelas circunstâncias enquanto interessar aos seus agentes. 0 facto de um texto estar relacionado com as pessoas de determinada comunidade (ou com determinada pessoa em concreto) não é sinónimo de o texto ali ter "nascido", e da pertença exclusiva àquele lugar, mas significa que o texto está vivo, que é energia, criou ligações com aquela comunidade e é essa ligação texto-comunidade que explica que ele ali exista. Esta afetividade pelo texto é construída em larga medida através das suas materialidades, é quando ele é cantado, dito, que se estabelece.

\section{Primeiras conclusões}

A variação é, nestes textos, com mais frequência, lexical, nomeadamente toponímica, como forma de ajuste semântico, e pragmático, ao lugar, patenteando a ligação Ecocrítica à terra, na transmissão, por exemplo, do tipo de trabalhos executados, e por quem, e em que estado se encontra o local.

Durante a aplicação dos critérios, e no âmbito léxico-gramatical, é notória a frequência de verbos ligados aos sentidos: cheirar; ver; ouvir; tocar; saber (gosto) e que estreitam, claramente, a relação entre o sujeito e o meio que o envolve.

Assim, entendem-se estes textos, orais e tradicionalistas, como modelos de pensamento--e de prática, que refletem as ligações entre o humano e o não humano e entre a atualidade e o tempo passado. No seio de uma moldura 
contemporânea caracterizada pela fugacidade dos acontecimentos, o Cante vem estreitar estas relações, evidenciando a importância de determinadas vivências e símbolos como alternativa a uma vida menos tecnológica. 0 Cante Alentejano surge como um género de literatura, onde a componente performativa, inequívoca, contribui para outras formas de interpretação, e, pela mão da Ecocrítica, pode encontrar formas de diálogo e modos de fazer mundos, na expressão de Nelson Goodman (1995).

De acordo com a noção de tradição em Octavio Paz, nos termos descritos em Santiago (2002, p. 119), esta traduz-se num empréstimo de um solo histórico que o poeta faz ao passado, permitindo a articulação da sua reação contra os princípios revolucionários impulsionadores da modernidade. De forma análoga, e quando se fala da tradição do e no Cante Alentejano, os Grupos Corais também o fazem: pedem emprestado ao "Alentejo passado" o solo histórico, a paisagem sonora, não num gesto de rebelião, como atrás se referia, mas numa postura que podemos considerar Ecocrítica, uma vez que revela um compromisso ideológico com a materialidade ambiental, na manutenção do lugar Alentejo, e simultaneamente, da sua (re)construção, perceção social e apego individual e coletivo a este mesmo lugar ${ }^{17}$.

À luz da teoria Ecocrítica, o Cante configura-se um catalisador da relação mais árdua entre o homem e a natureza: trabalhar a terra. Por exemplo, Manuel Felícia, um cantador alentejano que migrou para Tires, sublinha, em conversa informal, de trabalho de campo, o papel terapêutico do Cante Alentejano quando estava no Alentejo porque o ajudava a "passar melhor o tempo" durante o trabalho e, essa função parece manter-se na atualidade, mas pela razão oposta: porque está longe do campo. Já em Tires, 1975, quando Manuel Felícia formou o Grupo, relata que as letras que ia compondo se baseavam nessas lembranças da terra, do trabalho do campo, das precárias condições em que viveu e do que tinha passado no Alentejo. Sobre este processo de autoria, Manuel Felícia descreve-o desta forma: "ia recordando certas palavras e juntando outras, sobre a Aldeia Nova [S. Bento], a Barragem do Alqueva, a Reforma Agrária, as promessas feitas ao Alentejo por cumprir, nas letras só, as músicas são antigas." 0 autor remata afirmando que as letras que faz relatam o que se passou, o que se passa e o que pode ainda acontecer.

Nos vários fragmentos textuais, as temáticas das modas permanecem, atualmente, mas sustentam-se no mesmo pensamento metafórico, originando uma relação com o espaço mais teatral, o que provoca alterações semânticas ao nível do significado e do referente: o cantador que foi efetivamente ceifeiro assumirá um significado, e referente, diferentes do cantador jovem que nunca o

\footnotetext{
${ }^{17}$ Considere-se, por exemplo, o slogan evocado pelos Grupos Corais, vindos de várias localidades, incluindo Lisboa (Alcante Coral Alentejano: grupo recente da zona de Alcântara) a caminho da feira anual Ovibeja, abril, 2016: Eu amo o Alentejo que nos une e motiva, reunindo o individual e o coletivo na mesma frase. Assiste-se a uma visão urbana que vive com nostalgia o passado na letra do Cante reflete e colmata uma "falta de mundo" que os cantandores mais velhos parecem sentir.
} 
foi, partilhando só o seu significante aquando à execução vocal, quando o signo se torna matéria ou materialidade. Fala-se de uma relação espacial mais urbana absorvendo e refletindo o que social e historicamente acontece(u), como é próprio da oralidade.

Com efeito, recentes portadores do Cante Alentejano, ou novos inventores, tentam manter o cunho rural da prática, apesar da urbanidade e da progressiva perda de influência dos grupos tradicionais. Os grupos de cantadores estão, aos poucos, a renovar-se. Os mais novos conhecem e gostam das modas, e acabam por formar grupos, por uma questão de identificação porque viram atuações de outros grupos de jovens ou porque o Cante está "na moda". Acresce um tipo de poder implícito que os jovens adquirem através do cante mediático: um estatuto no seu grupo social, ou, para nos circunscrevermos à nossa área disciplinar, no seio da sua comunidade interpretativa, revelando uma outra perspetiva Ecocrítica, uma forma complementar de se relacionar com o meio envolvente, diferente da dos seus antecessores.

Esta fabricação de lugares, e no âmbito da Ecocrítica, pode assumir várias funções: para os elementos mais velhos podem surgir como lugares de reconciliação na revisitação de sítios como a planície, ou a beleza da paisagem, que inclui as aves ou as plantas, e para os portadores do Cante mais novos como lugares de conhecimento e de cidadania, onde podem aprender a importância da sua relação com o mundo físico e humano.

Neste tempo de globalização, em que a linha de força das várias áreas do saber contemporâneas converge para uma visão cosmopolita, urbana, o Cante Alentejano, também se assume como objeto global, não obstante a sua ligação a uma região. Nesta era tecnológica, a (re)produção e receção destes textos pode contribuir para aumentar a capacidade de resposta a um quadro de valores essenciais à relação entre o humano, a sociedade e o meio ambiente, enfraquecendo assim a ideia de Cante Alentejano como museu, no conceito tradicional e felizmente ultrapassado atribuído a esses espaços: lugar morto e hermético.

Com efeito, as modas podem configurar-se em microformas de representação da realidade, através dos pequenos elementos narrativos. Fala-se de uma poesia do concreto e não do abstrato, e da seleção de quadras que é feita pelos Grupos durante o processo de apropriação e de identificação, de forma a obter uma maior proximidade do lugar. Todavia, dentro de um quadro ficcional, porque literário, o aspeto interpretativo; ou do sentido, residirá nos modelos socioculturais, comuns ao universo rural, compreendidas como os valores que as regulam, desde os sociais e familiares aos religiosos e pagãos.

\section{Considerações finais}


Aferiu-se que as estrofes analisadas partilham do modelo do pensamento e expressão das culturas predominantemente orais, tendo confirmado o seu carácter fragmentário, quer pela viagem que as estrofes encetam, quer pela frequência de versos contagiosos nas várias modas.

Ao nível da análise formal, verificou-se como a metáfora, a comparação, a personificação, o vocativo, o leixa-prem e o estribilho se constituem recursos formais amplamente utilizados para expressar relações pessoais, emoções e sentimentos através de elementos da natureza ou do meio envolvente.

Desta forma, as modas alentejanas podem configurar-se em textos performativos, na medida em desvelam a importância das suas materialidades como interstícios hermenêuticos.

As letras contribuem para esta concretização, não tanto pelo significado da palavra, mas pelo seu significante, ou ainda, pelo esquema imagético desencadeado, por exemplo, a partir do item Alentejo, ou na receção de vocábulos como planície, campos, terra. Mais do que canções, as modas alentejanas revelam-se como experiências, se se pensar, por exemplo, nos relatos dos cantadores mais novos ao confessar que o Cante Alentejano lhes traz memórias que nunca tiveram, de coisas que nunca fizeram.

Observou-se que o enunciador-recetor, designação adotada por ser mais vocal, assume uma posição por vezes mais pragmática, quando relata rotinas, atividades laborais vivenciadas, oscilando entre o eu e o nós, e mais subjetiva, mais ideológica, nos textos de carácter tradicionalista, que constituem a maioria do corpus.

Reconhecem-se ainda estas composições como microformas de representação da realidade, através dos pequenos elementos narrativos, e da seleção de versos que é feita durante os processos de apropriação e de identificação, de forma a obter uma maior proximidade ao lugar.

Não obstante, será através do corpo e da voz, que toda a cultura de presença veiculada por estes modelos se concretiza. A variação é, com mais frequência, lexical nomeadamente toponímica, como forma de ajuste semântico, e pragmático, ao lugar, patenteando a ligação Ecocrítica à terra, na transmissão, por exemplo, do tipo de trabalhos executados, e por quem, e em que estado se encontra o local.

Como se verificou, sobretudo em performance, estes textos mostram não só a relação estreita e privilegiada do enunciador-recetor com o meio, mas também demonstram nessa mesma relação, as condições de vida do homem Alentejano em áreas ambientais problemáticas, como, por exemplo, o trabalho nas minas. Neste sentido, o olhar incide na relação de um Povo (auto)marginalizado - o Alentejano - numa perspetiva ambivalente onde o lugar Alentejo pode surgir, simultaneamente, como um lugar de conforto e um lugar de sofrimento. 
O lugar Alentejo surge então como o protagonista destes textos, uma vez que se constitui objeto privilegiado do sujeito enunciador-recetor, e, de alguma forma, respondemos afirmativamente à questão levantada por Cheryll Glotfelty: se lugar deveria ser elevada a categoria literária. Um sujeito que muitas vezes revela através das materialidades destas composições (voz dolente, corpo pesado, hermético), práticas de resistência numa paisagem maioritariamente rural e árida.

Com este artigo, pretende-se, de forma complementar, como aludido na introdução, a ampliação dos estudos literários, na expetativa de contagiar, ou estimular, futuros estudos teóricos, aplicados noutros objetos de estudo, e proporcionar, em última análise, uma visão da literatura oral, menos fragmentada ou desvalorizada. Sugere-se, por exemplo à Academia, a criação de um "Laboratório Ecocrítico" através da colaboração e participação dos vários departamentos implicados, como os de Literatura e Linguística e Ciências do Ambiente, ou ainda de Sociologia, ou de Antropologia, articulando os seus saberes e experiências visando o aprofundamento desta área, assentes numa metodologia comum. Nesta plataforma, recolher e analisar-se-iam textos, à luz dos pressupostos daqueles campos disciplinares, cruzando, por exemplo, a bissemiótica e a linguística, e, numa lógica transdisciplinar, propor outras performances $^{18}$.

\section{Referências}

AAVV. (1982). Revista A Tradição, I/ II [ed. fac-simile]. Serpa: Câmara Municipal de Serpa. Retirado de: http://www.archive.org/stream/tradio12lisbuoft\#page/n7/mode/2up (consultado em 2021-09-08)

Alves, I. M. F. (2013). Gardens in the Dunes: Indigenismo, natureza e poder em perspetiva ecocrítica, Revista Crítica de Ciências Sociais, 100, pp. 213-234.

Buell, L. (1996). The Environmental Imagination: Thoreau, Nature Writing and the Formation of American Culture. Cambridge/London: The Belknap Press of Harvard University Press.

Casaca, M. A. (2019-07-19). Neste Alentejo há caril e turbantes [transmissão radiofónica] TSF. https://www.tsf.pt/programa/reportagem-

\footnotetext{
18 Na verdade, poderão decorrer infinitas descobertas do cruzamento destas "combinações improváveis", refira-se, por exemplo, o trabalho de investigação, na universidade de Évora, de Mara Silva, em Bioquímica, que observa como alguns compostos produzidos por bactérias podem contribuir para a salvaguarda do património cultural.
} 
tsf/emissao/neste-alentejo-ha-caril-e-turbantes-11092749.html (consultado em 2021-09-08)

Coelho, T.N. (2019). Cante Alentejano, um lugar textual: contributos para o estudo de sentidos e materialidades literárias. Universidade de Évora: Évora.

Davidson, D. (1978). O que significam as metáforas. Pedro Serra (trad.) [Documento inédito]. https://www.academia.edu/13499733/_O_que_significam_as_met\%C3\%A1f oras_de_Donald_Davidson_Tradu\%C3\%A7\%C3\%A3o_de_Pedro_Serra_Docum ento_in\%C3\%A9dito_2002__(consultado em 2015-04-18)

Fish, S. (1982). Is There a Text in This Class? The Authority of Interpretive Communities: Harvard: Harvard University Press.

Garramuño, F. (s.d.). Poderes da afetividade: a destituição do sujeito e o seu potencial de resistência, 3 (pp. 215-228). Retirado de: http://www.casaruibarbosa.gov.br/escritos/numero03/FCRB_Escritos_3_11. Florencia_Garramuno.pdf (consultado em 2013-01-25)

Garrard, G. (2012). Ecocriticism: The new critical idiom. London: Routledge.

Glotfelty, C. \& Fromm, H., (eds.) (1996). The Ecocriticism Reader: Landmarks in Literary Ecology. Athens: University of Georgia Press.

Goodman, N. (1995). Modos de fazer mundos. Trad.: António Duarte. Lisboa: Edições Asa.

Gumbrecht, H. U. (2010). Produção de Presença: o que o sentido não consegue transmitir. Trad.: Ana Isabel Soares. Rio de Janeiro: Editora PUC RIO.

Lakoff, George (1987). Women, Fire, and Dangerous Things. What categories reveal about the mind. Chicago: The University of Chicago Press.

Lautensach, H. (1989). Povoamento, nomes de lugar e circulação. O. Ribeiro, H. Lautensach \& S. Daveau (Orgs.) (1989). In: Geografia de Portugal, III, (O Povo Português) (pp. 829-856). Lisboa: Edições João Sá da Costa.

Lewontin, R. (2002). A tripla hélice: gene, organismo e ambiente. Trad.: J. Vegas Filho. São Paulo: Companhia das Letras. 
Manes, C. (1996). Nature and silence. In: C. Glotfelty (Ed.), The Ecocriticism Reader- Landmarks in Literary Ecology (pp.15-29). Athens: University of Georgia Press.

Marvão, A. (1997). Estudos sobre o Cante Alentejano. Lisboa: Inatel.

Mendes, M.C. (2020). No Princípio era a Natureza: percursos da Ecocrítica. Anthropocenica. Revista de Estudos do Antropoceno e Ecocrítica 1: pp. 91-104

Popular (Alentejo), Monda e Ruben Alves (2016). Diz a Laranja ao Limão [música gravada por Monda]. Monda/TáNaForja.

Reino, J. P. (2000). Posse da Terra numa Freguesia do Alto Alentejo: A percepção da importância da posse da terra para a população residente da Aldeia da Luz. In: Arquivo de Beja, XIV, Série III (pp. 115 - 128). Retirado de: https://aps.pt/wp-content/uploads/2017/08/ensaio_ENS46fd194c075cb.pdf (consultado em 2019-06-15)

Ribeiro, O., Lautensach, H. \& Daveau, S. (org.) (1989). Geografia de Portugal, III, (O Povo Português). Lisboa: Edições João Sá da Costa.

Ribeiro, O. (1986). Portugal o Mediterrâneo e o Atlântico (4ª ed). Lisboa: Livraria Sá da Costa Editora.

RTP, Rádio e Televisão de Portugal (2014-08-27). 5 Para a Meia Noite [transmissão televisiva]. RTP1.

Rueckert, W. (1996). Literature and Ecology: An Experiment in Ecocriticism. In: Glotfelty, C. \& Fromm, H. (eds.), The Ecocriticism Reader. Landmarks in Literary Ecology (pp.105-123). Athens: University of Georgia Press.

Santiago, S. (2002). Nas malhas da letra: ensaios. Rio de Janeiro: Rocco.

Silko, L. M. (1999). Gardens in the Dunes. New York: Simon \& Schuster.

Tréfaut, S. (2013). Alentejo, Alentejo. [documentário]. N/C.

Zumthor, P. (2007). Performance, recepção, leitura ( $2^{\mathrm{a}}$ ed.). rad.: Jerusa Pires Ferreira e Suely Fenerich. São Paulo: Cosac Naify. 